\title{
Pengaruh Keteladanan Guru Pendidikan Agama Kristen Terhadap Pembentukan Karakter Siswa Di SMP PGRI Marinding Kelas II
}

\author{
Agus Kala' Padang, Ivan Th. J. Weismann
}

\begin{abstract}
Abstrak
Keteladanan merupakan dasar dari kegiatan pembelajaran dan ketika seorang guru tidak menggunakannya maka guru tersebut sudah mengurangi keefektifan pembelajaran. Jadi peran ini harus dipahami sehingga dapat memperkaya arti pembelajaran. Guru Pendidikan Agama Kristen harus memiliki sikap yang tulus dalam pengajarannya yakni menjadi teladan dalam hal pengetahuan, sikap hidup bagi para muridnya sehingga dapat mencerminkan hidup yang pantas dan layak sebagai teladan yang baik bagi muridnya khususnya dalam pembentukan karakter siswa. Karakter siswa bisa diubahkan apabila guru yang mengajar sudah menjadi model/teladan bagi muridnya. Adanya anak didik yang belum menampakan karakter yang baik akibat dari keteladanan seorang guru sehingga perlu dilakukan penelitian dengan tujuan mengetahui sejauhmana keteladanan guru Pendidikan Agama Kristen berpengaruh terhadap pembentukan karakter siswa di SMP PGRI Marinding. Penulis mengambil tempat penelitian di SMP PGRI Marinding dengan menggunakan metode penelitian kuantitatif dengan sampel penelitian 30 siswa. Dengan mengunakan angket, wawancara, dan observasi.

Hasil penelitian menunjukkan bahwa di SMP PGRI Marinding belum sepenuhnya guru Pendidikan Agama Kristen menunjukan keteladanan kepada siswa sehingga siswa belum menampakan karakter yang baik khususnya karakter peduli dan kerja keras. Oleh karena itu, guru Pendidikan Agama Kristen harus membereskan masa lalunya sehingga dapat menjadi guru yang dapat di teladani dalam iman, kasih, teladan dalam membaca Alkitab, teladan dalam perkataan, dan dalam tingkah laku.
\end{abstract}

Kata-kata Kunci: Keteladanan, Guru, Pendidikan, Agama, Kristen, Karakter, Siswa.

\section{Pendahuluan}

\section{Latar Belakang Masalah}

Menjadi seorang guru memiliki tanggung jawab yang sangat besar, di mana guru merupakan profesi yang sangat mulia dan merupakan suatu kepercayaan yang diberikan Tuhan bagi setiap orang. Guru merupakan faktor penting dalam menyukseskan kegiatan belajar mengajar. Di manapun kegiatan belajar-mengajar dilakukan di situ diharapkan ada guru berkualitas. Guru pula yang memberi dorongan agar peserta didik berani berbuat 
benar dan berani bertanggung jawab atas setiap perbuatannya. Dalam hal ini guru memberikan keteladanan, mamberikan contoh yang baik kepada peserta didiknya supaya dapat menirunya.

Pendidikan Agama Kristen sangat penting untuk membimbing anak didik ke arah yang lebih baik, karena Pendidikan Agama Kristen berfokus kepada pengajaran Alkitab yang merupakan otoritas tertinggi. Karena itu, John M. Nainggolan mengatakan, "Guru Pendidikan Agama Kristen harus memiliki sikap yang tulus dalam pengajarannya yaitu guru menjadi teladan dalam hal pengetahuan, sikap hidup dan dalam banyak hal bagi murid-muridnya. Oleh karena itu seorang guru harus senantiasa mencerminkan hidup yang pantas dan layak sebagai suatu teladan yang baik bagi murid-muridnya."1

Tuhan Yesus merupakan guru agung yang patut diteladani oleh setiap manusia. Tuhan Yesus merupakan seorang pengajar yang menyampaikan tentang kebenaran akan kerajaan Allah. Anak-anak di mata Tuhan Yesus sangat berharga, sesuai dengan Matius 19:14 "Tetapi Yesus berkata: Biarkanlah anak-anak itu, janganlah menghalang-halangi mereka datang kepada-Ku, sebab orang-orang yang seperti itulah yang empunya Kerajaan Sorga." Anak-anak merupakan bagian yang sangat penting di mata Tuhan, yang berarti tidak boleh dianggap sebelah mata.

Melihat pentingnya pendidikan dan penanganan terhadap anak-anak, maka guru merupakan panutan yang berpengaruh dalam pembentukan maupun perubahan perilaku anak. Dalam dunia pendidikan atau sekolah sebagai sumber ilmu memberikan tiga unsur pengetahuan yaitu unsur kognitif, afektif, dan psikomotor. Sekarang ini, guru tidak bisa lagi dijadikan sumber ilmu dari ketiga unsur pengetahuan ini, karena pengetahuan guru juga terbatas di tengah-tengah perubahan sosial yang sangat pesat dan berbagai pengetahuan dapat diambil dari internet. Namun unsur afektif yang harus diperoleh dari pendidikan tidak dapat diambil dari internet. Gurulah yang berperan memberikan pendidikan afektif ini. Salah satu fungsi afektif adalah pembentukan karakter para siswa. ${ }^{2}$

Salah satu kunci keberhasilan program pengembangan karakter siswa dalam pendidikan adalah keteladanan dari guru sendiri. Keteladanan bukan sekadar contoh bagi siswa, melainkan juga sebagai penguatan moral bagi siswa dan berperilaku. Oleh karena itu, penerapan keteladanan di dalam pendidikan menjadi persyaratan dalam pengembangan karakter siswa.

Guru memegang peran sangat penting dan harus tampil menjadi figur yang mampu memberikan contoh yang baik bagi siswanya. Guru mempunyai tanggung jawab untuk melihat segala sesuatu yang terjadi dalam kelas untuk membantu proses perkembangan anak didik. Guru merupakan orang yang memiliki peran sangat penting

1 John M. Nainggolan, Guru Agama Kristen Sebagai Panggilan dan Profesi Sebagai Upaya Peningkatan Mutu dan Kualitas Guru Agama Kristen (Bandung: Bina Media Informasi, 2010), 30.

2 Gama Septian Maulana, Hermanto, "Peran Keteladanan Guru Dalam Upaya Membentuk Karakter Peserta Didik Di SMA Negeri 12 Surabaya," Kajian Moral dan Kewarganegaraan 03, no. 2 (2014):1190, diakses 27 Februari 2018, http://jurnalmahasiswa.unesa.ac.id/index.php/jurnal-pendidikankewarganegaraan/article/download/9373/4049. 
dalam pembentukan karakter siswa. Anak didik yang berkarakter akan dapat meningkatkan derajat dan martabat bangsa. ${ }^{3}$

Di sinilah keteladanan seorang guru diperlukan untuk mampu berpartisifasi aktif dalam pembentukan karakter yang baik kepada anak didik sebagai bekal mereka agar mampu memilih jati diri yang benar sebagai anak-anak Tuhan, mampu menentukan setiap pergaulan yang mereka temukan. Berdasarkan pengamatan penulis, bahwa anak-anak didik yang ada di SMP PGRI Marinding belum memperlihatkan karakter yang memadai. Guru sebagai teladan dan pengajar karakter kepada siswanya dapat dikatakan bahwa guru yang berdampak dan mampu mengarahkan siswanya sesuai peraturan yang sudah ditentukan.

\section{Pokok Masalah}

Berdasarkan latar belakang di atas yang menjadi pokok masalah adalah: Sejauh mana keteladanan guru Pendidikan Agama Kristen berpengaruh terhadap pembentukan karakter siswa di SMP PGRI Marinding?

\section{Tujuan Penelitian}

Adapun tujuan yang hendak dicapai dalam penulisan ini sebagai berikut: Menjelaskan pengaruh keteladanan guru Pendidikan Agama Kristen terhadap pembentukan karakter siswa di SMP PGRI Marinding.

\section{Manfaat Penelitian}

Adapun manfaat penulisan skripsi ini adalah:

Pertama, diharapkan kepada setiap guru agar dapat menjadi teladan yang baik terhadap pembentukan karakter siswa.

Kedua, agar setiap guru memahami dan mengerti setiap karakter siswa.

Ketiga, untuk menambah wawasan yang baru kepada penulis dan pembaca khususnya bagi calon-calon guru agar mampu memperhatikan setiap karakter siswa yang diajar.

\section{Metode Penelitian}

Untuk mendapatkan data dan informasi yang berkaitan dengan skripsi ini, maka penulis menggunakan metode penelitian kuantitatif dengan beberapa model pengumpulan data sebagai berikut: pertama, menggunakan buku-buku, internet, kamus, sebagai bahan untuk membantu penulis dalam menyelesaikan skripsi ini yang berhubungan dengan pengaruh keteladanan guru Pendidikan Agama Kristen terhadap pembentukan karakter siswa. Kedua, mengadakan observasi atau penelitian langsung di lapangan dan mengadakan wawancara langsung dengan guru. Ketiga, memberikan angket kepada siswa. Tujuannya untuk mendapatkan data yang lebih akurat tentang pengaruh keteladanan Guru Pendidikan Agama Kristen terhadap pembentukan karakter siswa di SMP PGRI Marinding.

\footnotetext{
${ }^{3}$ Nisma Simorangkir, "Peran Guru Pendidikan Agama Kristen Dalam Pembentukan Karakter Anak Didik Melalui Proses Pembelajaran,” Jurnal Saintech 05, no.1 (Maret 2013):39, diakses 27 Februari 2018, http://docplayer.info/docview/52/29717440/.
} 


\section{Batasan Penelitian}

Dalam mengingat betapa pentingnya keteladanan guru Pendidikan Agama Kristen terhadap pembentukan karakter siswa maka penulis memberikan batasan penulisan yang mengacu pada keteladanan guru Pendidikan Agama Kristen terhadap pembentukan karakter siswa.

\section{Kesimpulan}

Berdasarkan hasil pengelolahan data dan pembahasan yang telah dilakukan dapat ditarik beberapa kesimpulan sebagai berikut:

Keteladanan seorang guru merupakan faktor penting dalam menyukseskan kegiatan proses belajar mengajar, di mana guru merupakan figur utama di sekolah yang harus memberi contoh kepada peserta didiknya dan mengajar mereka untuk memiliki karakter yang baik, untuk itulah keteladanan seorang guru perlu memiliki prioritas dalam pembentukan karakter peserta didiknya.

Keteladana seorang guru khususnya guru Pendidikan Agama Kristen sangat memberi pengaruh besar kepada anak didiknya di mana peserta didik dapat melihat langsung setiap apa yang dilakukan oleh gurunya baik lewat keteladanan yang sudah diberikan oleh guru seperti teladan dalam iman, teladan dalam kasih, teladan dalam membaca Alkitab, teladan dalam perkataan, dan teladan dalam tingkah laku.

Mengharapkan peserta didik memiliki karakter yang baik, maka seorang guru harus mendidik mereka sesuai dengan ajaran Alkitab. Guru harus meneladani Yesus sebagai pengajar yang berlandaskan ajaran Alkitab dan semua pengajarannya haruslah pengajaran firman Tuhan yang disampaikan.

Dalam beberapa karakter peserta didik yang diamati seperti karakter jujur, tanggung jawab, disiplin, adil, peduli, dan kerja keras. Dari beberapa karakter sebagian sudah dilakukan dan karakter peduli dan kerja keras masih sangat kurang dilakukan siswa karena guru yang kurang memberikan teladan yang benar, sehingga berdampak kepada peserta didik yang kurang peduli kepada temannya jika berada dalam kesusahan atau sakit dan kurang dalam berpartisipasi di masyarakat seperti gotong royong hal ini dipengaruhi oleh kurangnya partisipasi guru pada saat kerja bakti diadakan di sekolah. Keberadaan anak di sekolah merupakan tanggung jawab yang perlu diperhatikan oleh guru yakni mendidik, membimbing anak untuk tumbuh dewasa di dalam pengenalan akan Tuhan secara pribadi. Jadi keteladanan yang dominan dilakukan oleh guru PAK dan dapat berpengaruh kepada siswa adalah teladan tingkah laku. 


\section{Kepustakaan}

A., Doni Koesoema. Pendidikan Karakter. Jakarta: Gramedia Widiasarana Indonesia, 2007.

Abidin, Ahmad. Pendidikan Budi Pekerti. Bandung: Sinergi Pustaka Indonesia, 2007

Aeni, Ani Nur. Pendidikan Karakter Untuk Mahasisawa PGSD. Bandung: UPI Press, 2014.

Ali, Mohamad. Penelitian Kependidikan Prosedur dan Strategi. Bandung: Angkasa, 2013.

Astika, Made, DAN Bunga, Selvianty. "Hubungan Kompetensi Sosial Guru Kristen

Terhadap Perkembangan Karakter Siswa: Tantangan Pendidikan Kristen Dalam

Mencerdaskan Youth Generation" Jurnal Jaffray [Online], Volume 14 Nomor 1 (10 Maret 2016).

Bakthi, Dharma. Pencegahan Terhadap Bahaya Narkoba. Jakarta: Yayasan Purnabhakti Negara, 1999.

Beers, V. Gilbert. Orang Tua Berbicara Dengan Anak. Bandung: Yayasan Kalam Hidup, 2003.

Barnes, Robert G. Pedoman Bagi Para Orang Tua Tunggal. Bandung: Yayasan Kalam Hidup, 2000.

Black, James A. \& Dean J. Champion. Metode Dan Masalah Penelitian Sosial. Bandung: Refika Aditama, 1999.

Brubaker, J. Omar dan Robert B. Clark. Memahami Sesama Kita. Malang: Gandum Mas, 1972.

Buyung, Resy Nirawati. "Pengaruh Karakter Kerja Keras Terhadap Kemampuan Literasi Matematis Siswa Melalui Model Discovery Learning.” Jurnal Pendidikan Matematika Indonesia 3, No. 1 (Maret 2018):21-25. Diakses 9 Mei 2018. http://journal.stkipsingkawang.ac.id/index.php/JPMI/article/view/519/pdf.

Doherty, Sam. 100 Pertanyaan dan Jawaban Mengenai Penginjilan Kepada Anak. Jakarta: Lembaga Anak-Anak Indonesia, 2000.

Elia, Heman. Membentuk Sikap Hati Anak. Yogyakarta: Gloria Graffa, 2011.

Gondowijoyo, J. H. Sekolah Doa. Yogyakarta: ANDI, 2004.

Hadi, Sutrisno. Metodologi Research 2. Yogyakarta: Yayasan Penerbitan Fakultas Psikologi, 1986.

Jayanti, Agnesia, Elni Yakub, Romaswati. "Pengembangan Materi Pembentukan NilaiNilai Karakter Dalam Aspek Toleransi, Peduli Lingkungan, Dan Peduli Sosial Untuk Siswa SMK." Jurnal Online Mahasiswa (JOM) Bidang Keguruan dan Ilmu Pendidikan 3, No. 2 (2016):1-13. Diakses 8 Mei 2018. http://jom.unri.ac.id/index.php/Jomfkip/article/view/12067/11712.

Kurniawan, Syamsul. Pendidikan Karakter: Konsepsi \& Implementasinya Secara Terpadu Di Lingkungan Keluarga, Sekolah, Perguruan Tinggi, dan Masyarakat. Yogyakarta: Ar-Ruzz Media, 2013. 
Linda dan Richard Eyre. Mengajarkan Nilai-Nilai Kepada Anak. Jakarta: Gramedia, 1999.

Maulana, Gama Septian, Hermanto. "Peran Keteladanan Guru Dalam Upaya Membentuk Karakter Peserta Didik Di SMA Negeri 12 Surabaya." Kajian Moral dan Kewarganegaraan 03, No. 2 (2014):1189-1204. Diakses 27 Februari 2018. http://jurnalmahasiswa.unesa.ac.id/index.php/jurnal-pendidikan kewarganegaraan/article/download/9373/4049.

Mulyasa. Standar Kompetensi dan Sertifikasi Guru. Bandung: Remaja Rosdakarya, 2013.

Mulyasa, E. Manajemen Pendidikan Karakter. Jakarta: Bumi Aksara, 2014.

Musfah, Jejen. Manajemen Pendidikan Teori, Kebijakan, dan Praktik. Jakarta: Prenadamedia Group, 2015.

Nainggolan, John M. Guru Agama Kristen Sebagai Panggilan dan Profesi Sebagai Upaya Peningkatan Mutu dan Kualitas Guru Agama Kristen. Bandung: Bina Media Informasi, 2010.

Nazir, Moh. Metode Penelitian. Jakarta: Ghalia Indonesia, 1988.

Novi, Bunda. Tanya Jawab Seputar Parenting: Masalah-Masalah Umum Orang Tua Dalam Mendidik Anak. Yogyakarta: Flashbooks, 2015.

Nuhamara, Daniel. "Pengutamaan Dimensi Karakter Dalam Pendidikan Agama Kristen" Jurnal Jaffray [Online], Volume 16 Nomor 1 (19 Maret 2018)

Prihati, Tati. Menerapkan Moral Bagi Anak Usia Dini. Bandung: Bina Media Informasi, 2009.

Richards, Lawrence O. Pelayanan Kepada Anak-Anak. Bandung: Yayasan Kalam Hidup, 2007.

Rusyan, A. Tabrani. Siswa Teladan. Jakarta: Sinergi Pustaka Indonesia, 2006.

Sanjaya, H. Wina. Penelitian Pendidikan Jenis, Metode dan Prosedur. Jakarta: Prenadamedia Group, 2013.

Septiawani, Mary \& Stephen Tong. Seni Membentuk Karakter Kristen. Surabaya: Momentum, 2014.

Setiawani, Mery Go. Menerobos Dunia Anak. Bandung: Yayasan Kalam Hidup 2004.

Simanjuntak, Julianto \& Roswitha Ndraha. Tidak Ada Anak Yang Sulit. Yogyakarta: ANDI Offset, 2009.

Simorangkir, Nisma. "Peran Guru Pendidikan Agama Kristen Dalam Pembentukan Karakter Anak Didik Melalui Proses Pembelajaran.” Jurnal Saintech 05, No. 1 (Maret 2013):39 - 44. Diakses 27 Februari 2018.

http://docplayer.info/docview/52/29717440/.

Subagyo, Andreas B. Pengantar Riset Kuantitatif dan Kualitatif. Bandung: Yayasan Kalam Hidup, 2004.

Sumarna, Saleem Hardja. 108 Kepribadian Yang Paling Dicari Dan Disukai Oleh Siapapun, Kapanpun, Dan Dalam Kondisi Apapun. Yogyakarta: Galmas Publisher, 2015.

Tong, Stephen. Arsitek Jiwa. Jakarta: Lembaga Reformed Injili Indonesia, 1991.

Tu’u, Tulus. Pemimpin Kristen Yang Berhasil. Bandung: Bina Media Informasi, 2010. 
Usman, Husaini \& Purnomo Setiady Akbar. Metodologi Penelitian Sosial. Jakarta: Bumi Aksara, 1996.

Yaumi, Muhammad. Pendidikan Karakter Landasan, Pilar \& Implementasi. Jakarta: Prenadamedia Group, 2014.

Yeakley, Tom. Watak Kerja Kristus. Bandung: Kalam Hidup, 2008.

Wijaya, Hengki (ed.). Metodologi Penelitian Pendidikan Teologi. Makassar: Sekolah Tinggi Theologia Jaffray, 2016.

Zubaedi. Desain Pendidikan Karakter. Jakarta: Kencana Prenada Media Group, 2011. 